\title{
Numeric toys media: introducing number sense in early childhood with movement and multisensory cards
}

\author{
R. Fitri, Mustaji, B.S. Bachri \\ Universitas Negeri Surabaya \\ Surabaya, Indonesia \\ mustaji@unesa.ac.id
}

\begin{abstract}
The poor introduction of the concept of numbers in early childhood caused the number sense teaching to use too many worksheets. This study aims to introduce the effectiveness of numeric toys media in introducing number sense to improve the understanding of the concept of numbers in early childhood as a basis for learning mathematics in the next school level. The methods used follow the Borg and Gall model with the research subject of 36 children aged 5-6 years in Al Ibrah kindergarten, Gresik, Indonesia. The results showed a better understanding of the posttest after being given a learning with numeric toys media in the form of motion games and multisensory cards. This research provided an efficient idea of how to introduce number sense in kindergarten in a multisensory way and further research on the implications of this media on the mathematics of children in elementary school is still required.
\end{abstract}

Keywords-component; numeric toys media; early childhood; multysensory card

\section{INTRODUCTION}

Numeric toys media are developed for the interest of early childhood learning to introduce numbers with multisensory. These media are necessary considering the number sense learning has the problem of low ability to recognize the concept of numbers in children since the teaching process is still abstract. Since the early child is still in the stage of concrete thinking, introducing the concept of numbers need to use the media. By using media, abstract learning can be concretized and complex things can be simplified [22]. The needs of number sense learning required media design in accordance with the needs of children. Because it is used in early childhood, that still requires a lot of sensory stimulation, then the number sense learning media should be multisensory in order to involve all the senses covering visual, auditory, kinesthetic, and tactile, often called VAKT.

The condition of learning number sense in kindergarten is currently more on the aspect of counting $[14 ; 10]$ because there is mastery of calistung (read, write, count) for selection of elementary school (SD). Relax counting is a material that is abstract and learning activities structured way of thinking, thus, it is not suitable to teach children who have not been able to think structured. The introduction of the concept of numbers in early childhood determines success in learning mathematics in the next school level [8].

To overcome the problem of number sense learning in children due to his teaching using a lot of worksheets. The development of numeric toys media in the form of motion games and multisensory cards is required. The purpose of this study is to know the effectiveness of numeric toys media to introduce number sense in improving the understanding of the concept of numbers correctly as a capital of children to learn mathematics in primary school. This research provides teachers with an efficient idea of how to introduce a number sense in kindergarten and requires further research on the implications for mathematics skills in primary schools

\section{METHOD}

The development procedure in this study used the latest Borg and Gall development model [11] adapting the system approach developed by Dick and Carey covering the following 10 steps.

TABLE 1. Steps Borg and Gall development model

\begin{tabular}{|c|c|c|}
\hline No & Steps & Activity \\
\hline 1 & $\begin{array}{c}\text { Asses needs to } \\
\text { Identity } \\
\text { Instructional } \\
\text { Goals }\end{array}$ & $\begin{array}{c}\text { Identify the general objectives of } \\
\text { learning in the curriculum of early } \\
\text { childhood education cognitive } \\
\text { aspects for ages 5-6 years. }\end{array}$ \\
\hline 2 & $\begin{array}{c}\text { Conduct } \\
\text { Insructional } \\
\text { Analyze }\end{array}$ & $\begin{array}{c}\text { Determine what skills and } \\
\text { knowledge the students need in } \\
\text { achieving the goals. }\end{array}$ \\
\hline 3 & $\begin{array}{c}\text { Analyze Leaners } \\
\text { and Contexts }\end{array}$ & $\begin{array}{c}\text { Identifying the initial behavior and } \\
\text { characteristics of the child is done } \\
\text { through documentation, } \\
\text { observation and interview. }\end{array}$ \\
\hline
\end{tabular}




\begin{tabular}{|c|c|c|}
\hline No & Steps & Activity \\
\hline 4 & $\begin{array}{c}\text { Write } \\
\text { Performance } \\
\text { Objective }\end{array}$ & $\begin{array}{c}\text { Formulating specific instructional } \\
\text { objectives cognitive aspect } \\
\text { according to the number sense } \\
\text { material. }\end{array}$ \\
\hline 5 & $\begin{array}{l}\text { Develop } \\
\text { Assessment } \\
\text { Instrument }\end{array}$ & $\begin{array}{l}\text { Compile an observation tool to } \\
\text { measure the ability of number } \\
\text { sense. Child work results are } \\
\text { observed and measured using } \\
\text { Rating Scale. }\end{array}$ \\
\hline 6 & $\begin{array}{c}\text { Develop } \\
\text { Instructional } \\
\text { Strategy }\end{array}$ & $\begin{array}{c}\text { Preparing a daily learning plan to } \\
\text { use a media number sense of } 6 \\
\text { meetings. }\end{array}$ \\
\hline 7 & $\begin{array}{l}\text { Develop And } \\
\quad \text { Select } \\
\text { Instructional } \\
\text { Materials }\end{array}$ & $\begin{array}{l}\text { Developing instructional materials } \\
\text { in the form of teacher manual and } \\
\text { media number sense for early } \\
\text { childhood. }\end{array}$ \\
\hline 8 & $\begin{array}{l}\text { Design And } \\
\text { conduct } \\
\text { Formative } \\
\text { Evaluation of } \\
\text { Instruction }\end{array}$ & $\begin{array}{l}\text { Conducting formative evaluation } \\
\text { in the form of expert validation, } \\
\text { one-on-one testing, large group } \\
\text { trials, field trials }\end{array}$ \\
\hline 9 & $\begin{array}{c}\text { Revise } \\
\text { Instruction }\end{array}$ & $\begin{array}{l}\text { Make revisions based on } \\
\text { validation and trial results. }\end{array}$ \\
\hline
\end{tabular}

Development steps are only done until the 9th stage that is only until the revision of product development design so that the product is ready to use.

Methods of data collection used observation, interview and questionnaire. The implementation of the validation includes four stages, namely: 1) Expert review, using a questionnaire given to a material expert, a design instructional expert, and a media expert; 2) one-to-one tests with interview sheets for 5 children of K-2; 3) large group trials, with interview sheets for 13 children of $\mathrm{K}-2$; 4) field trials using experiments with observation sheets to compare children's number sense achievement at pretest and posttest for 36 children of K-2

\section{RESULT AND DISCUSSION}

The results of data analysis development of the numeric toys media products for early childhood showed the trial results feasibility of material experts, media experts, design experts, and group trials and show effectiveness in learning and increasing ability to recognize numbers proven through test results Try the field. The results of the trial can be seen in the following table.
TABLE 2. Result of expert adjustment and field trials.

\begin{tabular}{|c|c|c|}
\hline Validation & $\%$ & Revision \\
\hline Material experts & 97,37 & $\begin{array}{c}\text { Language in the guide } \\
\text { book }\end{array}$ \\
\hline $\begin{array}{c}\text { Media expert } \\
\begin{array}{c}\text { One-to-one } \\
\text { trials }\end{array}\end{array}$ & 95,25 & Media size (on 3 pieces) \\
\hline Group trials & 98,35 & Addition of color type \\
\hline
\end{tabular}

The result of data analysis on field trial using pairedsamples t-test showed the mean difference between pretest of 52.69 The test participants were $\mathrm{N}=36$; Std deviation $=9.058$ and mean posttes equal to 68.39 ; The test participants were $\mathrm{N}=$ 36 ; Std deviation $=6.447$.

The magnitude of correlation between pretest and posttes was equal to 0909 with significance level of 0.000 . Based on the analysis results, it was obtained sig value. of 0,000 , where the value of $\alpha=0.05$ is greater than sig. Then $\mathrm{Ha}$ accepted $\mathrm{Ho}$ rejected. This means that there are differences in learning outcomes after using the numeric toys media for early childhood that has been developed.

This development has resulted in instructional media and number sense guidebook for early childhood. The 19 learning media produced were in the form of numeric toys to help the understanding of the concept of numbers that include: calculate, match, sort, addition and subtraction, comparison, and pattern.

Numeric toys media are multisensory involving children's learning modality that are visual (sight), auditory (hearing), kinesthetic (movement), and tactile (touch). The form of media is a variety of number cards, rubber counters with various colors, and some media from flannel. These media can be used to introduce the concept of sequence, comparison, pairing, patterns, additions and subtractions by playing with movements such as jumping or clapping. The teacher manual contains the concept of number sense and explanation of the learning steps of each type of media to introduce concepts of numbers and their operations concretely. Numeric toys media introduced number sense through motion games and number cards aimed at increasing the ability to recognize numbers correctly.

This is in accordance with research conducted by Bano that the success of understanding the concept of numbers due to the support of number sense learning through exploration activities using concrete media $[2 ; 21 ; 6]$. In addition, the results of research written by Griffin that learning sense in the Kindergarten will increase the mastery of numbers.

\section{CONCLUSION}

Based on the results of data analysis, it can be said that there was a difference in the average value of pretest with posttes value in the learning process using the numeric toys media in the form of motion games and multisensory cards. 
The mastery of basic mathematics concepts and teacher creativity in variation of game idea using numeric toys media is very important and influential on achievement of children's number sense. This requires training for teachers to have a proper understanding of the basic mathematical concepts and be able to use this medium in introducing the number sense in early childhood. This research provides an efficient idea of how to introduce a number sense multisensory in kindergarten as well as to give ideas of various media in accordance with the number sense material so that teachers can further develop their own effective media for teaching in the classroom. Future research is expected to find the implications of applying the numeric toys media in mathematics subject to the late kindergarten up to those in elementary school.

\section{REFERENCES}

[1] Bambini.2010. Montessori early childhood education mathematics. Amerika:Bambini Montessori Materials.

[2] Bano, N.2012. Developing number sense in young children through collaborative action research (Unpublished master's article). Desertasi. Pakistan: Aga Khan University, Karachi.

[3] Burn, M.2007. About teaching mathematics a k-8 resource. 3nd Edition. California: Math Solution Publication.

[4] Booth, J. L., McGinn, K. M., Barbrieri, C., Begolli, K. N., Chang, B., Miller-Cotto, D.,\& Davenport, J. L.2017. Evidence for cognitive science principles that impact learning in mathematics. Acquisition of complex arithmetic skills and higher-order mathematics concepts, 3, 297-325.

[5] Charlesworth, R. 2005. Experiences in math for young children. Fifth Edition. United States:Thomson Delmar Learning.

[6] Clements, D. H.2000. 'Concrete'manipulatives, concrete ideas. Contemporary Issues in Early Childhood, 1(1), 45-60.

[7] Dewantara, K. H.2013. Pendidikan. Yogyakarta: Majelis Luhur Persatuan Taman Siswa.

[8] Dyson, N. I., Jordan, N. C., \& Glutting, J.2013. A number sense intervention for low-income kindergartners at risk for mathematics difficulties. Journal of Learning Disabilities, 46(2), 166-181.

[9] Feldman, J. R.2005. A survival guide for the preschool teacher. New York: The Center For Applied Research and Education.

[10] Fuson, K. C.2012. Children's counting and concepts of number. Springer Science \& Business Media.
[11] Gall, M.D., Gall, J., dan Borg, W. R.2007. Educational research an introduction. Boston: Pearson: Education, Inc.

[12] Griffin, S.2004. Teaching Number Sense. Improving Achievement in Math and Science,61(5), 39-42.

[13] Handayani, DN.2010. The early development of number sense with the support of structuring.http://p4 mriunismuh.wordpress.com/2010/09/27/the-early-development-ofnumber-sense-with-the-support-of-structuring-a-design-research-onnumber-sense-by-d-n-handayani/. Diunggah2 November 2012.

[14] Jordan, N. C., Kaplan, D., Nabors Oláh, L., \& Locuniak, M. N.2006. Number sense growth in kindergarten: A longitudinal investigation of children at risk for mathematics difficulties. Child development, 77(1), 153-175.

[15] Oppermann, E., Anders, Y., \& Hachfeld, A.2016. The influence of preschool teachers' content knowledge and mathematical ability beliefs on their sensitivity to mathematics in children's play. Teaching and Teacher Education, 58, 174-184.

[16] Pollitt, R., Cohrssen, C., Church, A., \& Wright, S.2015. Thirty-one is a lot! Assessing four-year-old children's number knowledge during an open-ended activity. Australasian Journal of Early Childhood,40(1), 13.

[17] Ren.2009. Number sense. http://theawakeningofmind.blogspot.com/2009/02/ number-sense.html. Diungguh 30 November 2012.

[18] Reys, R. E., Lindquist, M., Lambdin, D. V., \& Smith, N. L. 2014. Helping children learn mathematics. John Wiley \& Sons.

[19] Ruseffendi. $2005 . \quad$ http://repository. upi.Edu/operator/upload/s_pgsd_0904883_ chapter2.pdf. Diungguh 30 November 2012.

[20] Seldin, Tim.2006. How to raise an amazing child the Montessori way. New York: DK Publishing.

[21] Starkey, P., Klein, A., \& Wakeley, A.2004. Enhancing young children's mathematical knowledge through a pre-kindergarten mathematics intervention. Early Childhood Research Quarterly, 19(1), 99-120.

[22] Sudjana, N., Riva`i, A.2010. Media pengajaran. Bandung: Sinar Baru Algensindo.

[23] Susanto, A.2011. Perkembangan anak usia dini Pegantar dalam berbagai aspeknya. Jakarta: Kencana.

[24] Uttal, D. H., Scudder, K. V., \& DeLoache, J. S.1997. Manipulatives as symbols: A new perspective on the use of concrete objects to teach mathematics. Journal of applied developmental psychology, 18(1), 3754.

[25] Wening.2012. Bunda sekolah pertamaku. Solo: Tinta Medina. 